\title{
Microtopographic variation in soil respiration and its controlling factors vary with plant phenophases in a desert-shrub ecosystem
}

\author{
B. Wang ${ }^{1,2}$, T. S. Zha ${ }^{1}$, X. Jia ${ }^{1,2}$, J. N. Gong ${ }^{2}$, B. Wu ${ }^{1}$, C. P. A. Bourque ${ }^{3}$, Y. Zhang ${ }^{1}$, S. G. Qin ${ }^{1}$, G. P. Chen ${ }^{4}$, and \\ H. Peltola ${ }^{2}$
}

${ }^{1}$ Key Laboratory of Soil and Water Conservation and Desertification Combating, School of Soil and Water Conservation, Beijing Forestry University, Beijing 100083, China

${ }^{2}$ School of Forest Sciences, University of Eastern Finland, P.O. Box 111, 80101 Joensuu, Finland

${ }^{3}$ Faculty of Forestry and Environmental Management, University of New Brunswick, Fredericton, New Brunswick, E3B 5A3, Canada

${ }^{4}$ Institute of Forestry Sciences, Bailongjiang Forestry Management Bureau of Gansu Province, 746010, China

Correspondence to: T. S. Zha (tianshanzha@bjfu.edu.cn)

Received: 13 March 2015 - Published in Biogeosciences Discuss.: 25 June 2015

Revised: 17 September 2015 - Accepted: 21 September 2015 - Published: 8 October 2015

\begin{abstract}
Soil respiration $\left(R_{\mathrm{S}}\right)$ and its biophysical controls were measured over a fixed sand dune in a desertshrub ecosystem in northwest China in 2012 to explore the mechanisms controlling the spatial heterogeneity in $R_{\mathrm{S}}$ and to understand the plant effects on the spatial variation in $R_{\mathrm{S}}$ in different phenophases. The measurements were carried out on four slope orientations (i.e., windward, leeward, north- and south-facing) and three height positions on each slope (i.e., lower, upper, and top) across the phenophases of the dominant shrub species (Artemisia ordosica). Coefficient of variation (i.e., standard deviation/mean) of $R_{\mathrm{S}}$ across the 11 microsites over our measurement period was $23.5 \%$. Soil respiration was highest on the leeward slope, and lowest on the windward slope. Over the measurement period, plant-related factors, rather than microhydrometeorological factors, affected the microtopographic variation in $R_{\mathrm{S}}$. During the flower-bearing phase, root biomass affected $R_{\mathrm{S}}$ most, explaining $72 \%$ of the total variation. During the leaf coloration-defoliation phase, soil nitrogen content affected $R_{\mathrm{S}}$ the most, explaining $56 \%$ of the total variation. Our findings highlight that spatial pattern in $R_{\mathrm{S}}$ was dependent on plant distribution over a desert sand dune, and plantrelated factors largely regulated topographic variation in $R_{\mathrm{S}}$, and such regulations varied with plant phenology.
\end{abstract}

\section{Introduction}

Soil respiration $\left(R_{\mathrm{S}}\right)$ plays an important role in the global carbon (C) cycle (Bond-Lamberty and Thomson, 2010a). Even relatively small increases in $R_{\mathrm{S}}$ may have a profound impact on atmospheric $\mathrm{CO}_{2}$ concentrations, exerting a positive feedback to global warming (Schlesinger and Andrews, 2000; Davidson and Janssens, 2006; Luo, 2007). However, estimating soil $\mathrm{C}$ release is usually difficult at large spatiotemporal scales, mainly due to the strong heterogeneity in $R_{\mathrm{S}}$ (BondLamberty and Thomson, 2010b; Luo et al., 2012; Jia et al., 2013). Such heterogeneity depends strongly on the variability of substrate of respiration (e.g., soil organic matter and living biomass, Martin and Bolstad, 2009; Geng et al., 2012; Ngao et al., 2012) and hydrometeorological factors (e.g., soil water content (SWC) and soil temperature $\left(T_{\mathrm{S}}\right)$; Marrin and Bolstad, 2009; Ngao et al., 2012).

Arid, semiarid and dry-subhumid ecosystems occupy $41 \%$ of the terrestrial surface (Safriel and Adeel, 2005). The C cycle in desert ecosystems cannot be ignored in the global C cycle (Austin, 2011; Poulter et al., 2014). $R_{\mathrm{S}}$ represents the second largest $\mathrm{C}$ flux between ecosystems and the atmosphere (Raich and Schlesinger, 1992; Raich et al., 2002), and exhibits high spatial variation in desert ecosystems (Mahall et al., 1992; Gold et al., 1995; Xie et al., 2001). In addition, active, semi-active aeolian, and fixed sand dunes are the primary features of desert landscapes. Since the greatest amount 
of living biomass occurs on fixed sand dunes (Roles et al., 2001), its $R_{\mathrm{S}}$ contributes significantly to $\mathrm{C}$ emissions to the atmosphere. Thus, for accurate regional $\mathrm{C}$ estimates, it is necessary to understand the mechanisms driving spatial pattern in $R_{\mathrm{S}}$ over fixed sand dunes.

Generally, topographic variation in $R_{\mathrm{S}}$ in arid and semiarid areas can be explained by hydrometeorological factors alone, especially by SWC (Xu and Wan, 2008; Liu et al., 2010). This is because $T_{\mathrm{S}}$ and SWC are reported to have a strong primary control on the spatiotemporal variation in $R_{\mathrm{S}}$ (Lloyd and Taylor, 1994; Davidson et al., 1998; Wang et al., 2014), as they both exhibit significant heterogeneity as a result of the influence of topography in governing the amount of solar radiation received and the re-distribution of surface and shallow subsurface water (Kang et al., 2003; Liu et al., 2010). Heterogeneity in microhydrometeorological factors also has an explicit role in defining the formation and patchy distribution of vegetation growing in an area (Richerson and Lum, 1980; Parker, 1991). Distribution of vegetation, in turn, constrains the spatial variation in $R_{\mathrm{S}}$ through its patchy supply of substrate to $R_{\mathrm{S}}$. In desert ecosystems, such plant effects usually relate to a phenomenon called "fertility islands". This phenomenon is observed by the enrichment of water, nutrient, and root biomass in vicinity of plant canopies (Hook et al., 1991; Schlesinger and Raikes, 1996), resulting from several plant-scale processes, including plant-facilitated entrapment of soil particles and organic matter propelled by wind or rain droplets, canopy shading, hydraulic lift, and accumulation and decomposition of litterfall (Schlesinger and Raikes, 1996; Stock et al., 1999; Thompson et al., 2005; J. Li et al., 2007; P. X. Li et al., 2008). Consequently, plant controls on $R_{\mathrm{S}}$ could be nested within microhydrometeorological controls, leading to greater complexity in plant-soil interaction.

Moreover, both microhydrometeorological and plant control could vary with plant phenophases (Fu et al., 2002; Dungan et al., 2003; Kang et al., 2003; Yuste et al., 2004; Tang et al., 2005; Tamai, 2010; Asaeda and Rashid, 2014; Osono, 2014), as current photosynthate supply and decomposition and supplementation of litterfall changes over time. For example, root activity and rhizosphere processes could vary with plant phenophases (Fu et al., 2002), and potentially alter the relationship between $R_{\mathrm{S}}$ and $T_{\mathrm{S}}$ (Yuste et al., 2004; DeForest et al., 2006). Previous studies have focused on the influences of plant phenology on the temporal dynamics of $R_{\mathrm{S}}$. However, understanding the temporal changes in effects of plants on the spatial variation in $R_{\mathrm{S}}$ is still an important gap in our knowledge concerning plant-soil interactions in desert environments.

We hypothesized that over a fixed sand dune: (1) topographic heterogeneity in $R_{\mathrm{S}}$ is controlled to a large measure by the distribution of substrate of respiration supplied by the annual casting of plant photosynthates and nitrogen compounds during leaf-fall; and (2) drivers of topographic variation in $R_{\mathrm{S}}$ vary with plant phenology. To test our hypothesis, $R_{\mathrm{S}}$ and associated microhydrometeorological and plant-related factors were measured over a fixed sand dune in a desert-shrub ecosystem in northwest China.

\section{Materials and methods}

\subsection{Site description}

The study was conducted on a fixed sand dune at Yanchi Research station of Beijing Forestry University, Ningxia, northwest China (107.20-107.26 E, 37.68$37.73^{\circ} \mathrm{N}, 1550 \mathrm{~m}$ a.s.1.). The site is located at the edge of the $\mathrm{Mu}$ Us desert in a transition zone between arid and semiarid climatic conditions. Based on 51 years (1954-2004) of data from the meteorological station of Yanchi County, the mean annual temperature is $8.1^{\circ} \mathrm{C}$. The mean annual precipitation is $292 \mathrm{~mm}$ (with a range of $250-350 \mathrm{~mm}$ ), of which $62 \%$ falls between July and September, and the mean annual total potential evaporation is $2024 \mathrm{~mm}$ (Wang et al., 2014). The sandy soil has a bulk density of $1.6 \pm 0.02 \mathrm{~g} \mathrm{~cm}^{-3}$. The water-filled pore space across all the microsites was $23.42 \pm 0.92 \%$. Soil organic matter, $\mathrm{CaCO}_{3}$ content and $\mathrm{pH}$ were $0.21-2.14,0.23-0.54$, and $7.76-9.08 \mathrm{~g} \mathrm{~kg}^{-1}$, respectively (Feng et al., 2013). The vegetation at our study site was regenerated since aerial seeding in 1998 and was dominated by semi-shrub species of is Artemisia ordosica, which averaged $50 \mathrm{~cm}$ tall with a canopy size of about $80 \mathrm{~cm} \times 60 \mathrm{~cm}$. The coverage percentage of plant in this area ranged from 30 to $60 \%$.

\subsection{Measurements of soil $\mathrm{CO}_{2}$ efflux and microhydrometeorological factors}

Soil $\mathrm{CO}_{2}$ efflux $\left(R_{\mathrm{s}}, \mu \mathrm{mol} \mathrm{CO} \mathrm{CO}_{2} \mathrm{~m}^{-2} \mathrm{~s}^{-1}\right)$ was measured with 11 automated chambers from June to October 2012. The measurements were taken on different slope orientations (i.e., windward in the east, leeward in the west, and northand south-facing slopes) and positions (i.e., lower, upper and top positions) on a typical shrub-dominated sand dune. The sand dune was of typical size for the study area, with a (i) height of $2.9 \mathrm{~m}$, (ii) $7.6 \mathrm{~m}$ long leeward slope, (iii) $15.6 \mathrm{~m}$ long windward slope, (iv) $13.3 \mathrm{~m}$ long north-facing slope and (v) $13.4 \mathrm{~m}$ long south-facing slope. Soil respiration was measured in situ using an automated chamber system (model Li-8100A, equipped with Li-8150 multiplexer, LI-COR, Nebraska, USA). Measurements were made along two $26 \mathrm{~m}$ line transects that intersected at perpendicular angles at the center of the sand dune (Fig. 1). The $R_{\mathrm{S}}$ system included the installation of 11 permanent opaque chambers set on PVC collars (model Li-104, LI-COR, Nebraska, USA). The collars, with a diameter of $20.3 \mathrm{~cm}$ and a height of $10 \mathrm{~cm}$, were inserted into the soil at a $7 \mathrm{~cm}$ depth. The chambers were located at about 3 to $5 \mathrm{~m}$ apart along the line transects, each placement representing different sand-dune microsites: top (position 1); upper parts of both the windward (position 2) and leeward slopes (position 7); lower parts of both the windward (posi- 


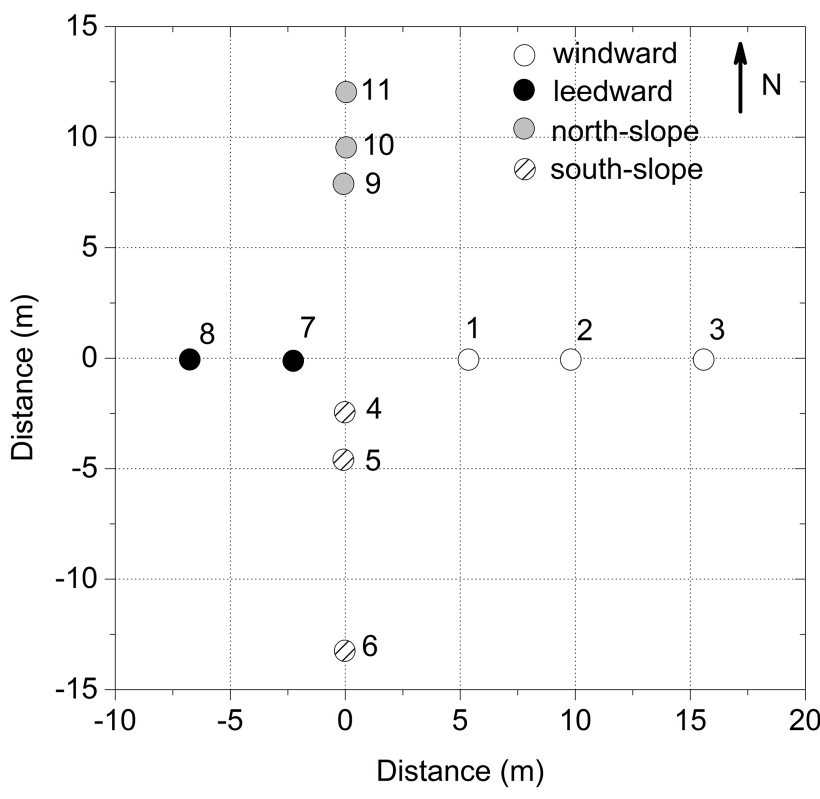

Figure 1. Schematic of measurement positions (11) distributed on four slopes (windward, leeward, north- and south-facing slope) over a fixed sand dune as well as plot positions and labels.

tion 3) and leeward slopes (position 8); and the microsites from top to the bottom of both the south-facing (position 4 , 5,6 ) and north-facing slopes (position 9, 10, 11; Fig. 1).

Soil respiration measurement time for each chamber was $3 \mathrm{~min}$ and $15 \mathrm{~s}$, including a $30 \mathrm{~s}$ pre-purge, a $45 \mathrm{~s}$ post-purge, and a 2 min observation period. Any plant re-growth within the measurement collar was manually removed in a timely manner. Hourly soil temperature $\left(T_{\mathrm{s}},{ }^{\circ} \mathrm{C}\right)$ and volumetric soil water content $\left(\mathrm{SWC}, \mathrm{m}^{3} \mathrm{~m}^{-3}\right)$ were measured simultaneously at a $10 \mathrm{~cm}$ depth outside of each chamber using 8150-203 soil temperature and $\mathrm{EC}_{\mathrm{H} 2 \mathrm{O}}$ soil moisture sensors (LI-COR, Nebraska, USA). For more details concerning measurement protocol for $R_{\mathrm{S}}, \mathrm{SWC}$, and $T_{\mathrm{S}}$, see Wang et al. (2014).

\subsection{Measurements of plant-related factors}

Plant-related factors considered in this work were root biomass $\left(\mathrm{kg} \mathrm{m}^{-3}\right)$, litterfall $\left(\mathrm{kg} \mathrm{m}^{-2}\right)$, total soil nitrogen content $\left(\mathrm{g} \mathrm{kg}^{-1}\right)$ within the first $25 \mathrm{~cm}$ of the soil, leaf area index (LAI, $\mathrm{m}^{2} \mathrm{~m}^{-2}$ ), and plant phenophases. Usually soil samples were collected near each $R_{\mathrm{S}}$ chamber on the 15th and 30th day of each month using a soil corer $(25 \mathrm{~cm}$ in height and $5 \mathrm{~cm}$ in diameter). However, collection of soil samples was delayed for several days after rain events to avoid its effects on soil nitrogen content. Three soil replicates were taken near each collar (within $0.5 \mathrm{~m}$ ), and mixed before they were air dried and sieved through 1, 0.5 and $0.25 \mathrm{~mm}$ meshes. During sieving, roots and litterfall were first picked up manually, and scraps of litterfall remaining were separated from the sand by washing the sample with clean water. Dead and alive roots

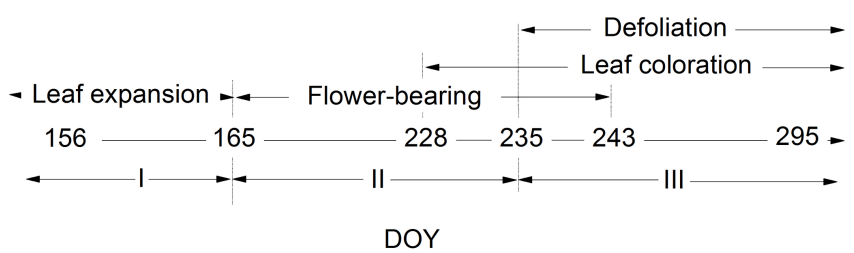

Phase I: leaf expansion (9 days)

Phase II: flower-bearing (70 days)

Phase III: coloration-defoliation (60 days)

Figure 2. Phenophases of Artemisia ordosica over the measurement period. Three phases are considered, included leaf expansion (phase I), flower-bearing (phase II), and leaf coloration-defoliation (phase III) phases.

were sorted out by color. The black ones were dead roots and mixed with litterfall as the litterfall sample. The yellow ones were alive roots. Both alive roots and litterfall samples were oven dried at $70^{\circ} \mathrm{C}$ to a constant weight. Then the soil samples were sieved through a $0.25 \mathrm{~mm}$ mesh for total soil nitrogen measurements. Total nitrogen in the soil was determined with a Kjeldahl Total Nitrogen Apparatus (FOSS 2200, Foss, Denmark).

LAI was measured near each chamber within one hour immediately after sunset using LI-COR 2000 (LI-COR, Nebraska, USA) with a $90^{\circ}$ view cap, twice or three times every month during the measurement period. At each measurement time, LAI was measured close to ground surface in eight directions, which were roughly uniformly distributed within a $0.5 \mathrm{~m}$ radius around the chamber, in order to well reflect the effect of vegetation around. Final output of LAI value was the mean of the eight records of the eight directions. In addition, the phenological phases of Artemisia ordosica were observed and recorded over the growing season at weekly intervals. Three obvious phases identified were leaf expansion (phase I), flower-bearing (phase II), and leaf colorationdefoliation (phase III; Fig. 2).

\subsection{Data analysis}

Due to fewer measurements in Phase I, data analyses were mainly concentrated on Phase II and Phase III. Hourly $R_{\mathrm{S}}$ data were first screened and values beyond the range of -1 to $15 \mu \mathrm{mol} \mathrm{CO} \mathrm{Cm}^{-2} \mathrm{~s}^{-1}$ (mean \pm 5 standard deviation) were removed from the data set as spurious values (Wang et al., 2014). Instrument failure and quality control procedures resulted in the removal of about $3 \%$ of the data from 4 June to 22 October 2012. The days of rainfall were also excluded during our analyses. Daily mean values (total $n=92$ ) of $R_{\mathrm{S}}$, $T_{\mathrm{S}}$ and SWC were used in further analyses. We assumed these biweekly measurements of LAI (total $n=8$ ), roots (total $n=7$ ), litterfall (total $n=7$ ) and soil nitrogen (total $n=7$ ) represent or reflect the average variation over the defined time period, because those variables are slow responsive fac- 
tors to environmental changes and remain relatively stable over a 2-week period. The point values in the regression for target variables represent the average characteristics over the defined time period. We calculated the daily coefficient of variation $\left(\mathrm{CV}\right.$, standard deviation/mean) in $R_{\mathrm{S}}$ across the 11 positions as a metric of spatial variability. CV for each of the phenophases or the whole measurement period was calculated as a mean of daily $\mathrm{CV}$ over the corresponding period.

Pearson correlation and regression analyses were used to examine the relationship between $R_{\mathrm{S}}$ and microhydrometeorological and plant-related factors. Class and Regression Tree analyses (CART) were used to explore the main factors controlling spatial variability in $R_{\mathrm{S}}$ (Breiman et al., 1984). We excluded measurements during rainfall events in both the correlation and CART analyses, due to the prevalence of $\mathrm{CO}_{2}$ flux pulses during these events (Fig. 5 in Wang et al., 2014). In CART analyses, we first set the split value to 1 , and then used cost-complexity tree pruning based on a 10-fold crossvalidation (Venables and Ripley, 2002). All statistical analyses were performed in Matlab (R2010b, Mathworks Inc., Natick, MA, USA); the significance level was set at 0.05 .

\section{Results}

\subsection{Topographic heterogeneity in plant-related and microhydrometeorological factors, and in soil respiration}

Plant-related factors (i.e., litterfall, root biomass and soil nitrogen) except LAI, exhibited large spatial heterogeneity (Table 1, Fig. 3). The mean daily CVs of litterfall, root biomass and soil nitrogen were 82.0, 64.7, and $49.1 \%$, respectively (Table 1). In contrast, among the four slopes, the microhydrometeorological factors exhibited only minor spatial variation (Table 1, Fig. 3). The mean daily CVs of $T_{\mathrm{S}}$ and SWC were only 4.6 and $22.0 \%$, respectively (Table 1). Among the four slopes, mean SWC changed very little $\left(0.01-0.03 \mathrm{~m}^{3} \mathrm{~m}^{-3}\right.$; Table 2). Soil temperature $\left(T_{\mathrm{s}}\right)$ differed among the four slopes $(p<0.001)$, with mean differences ranging from 0.5 to $2.4^{\circ} \mathrm{C}$ (Table 2). Among the three height positions (lower, upper and top positions), there was no consistent pattern in both plant-related and microhydrometeorological factors (Fig. 3).
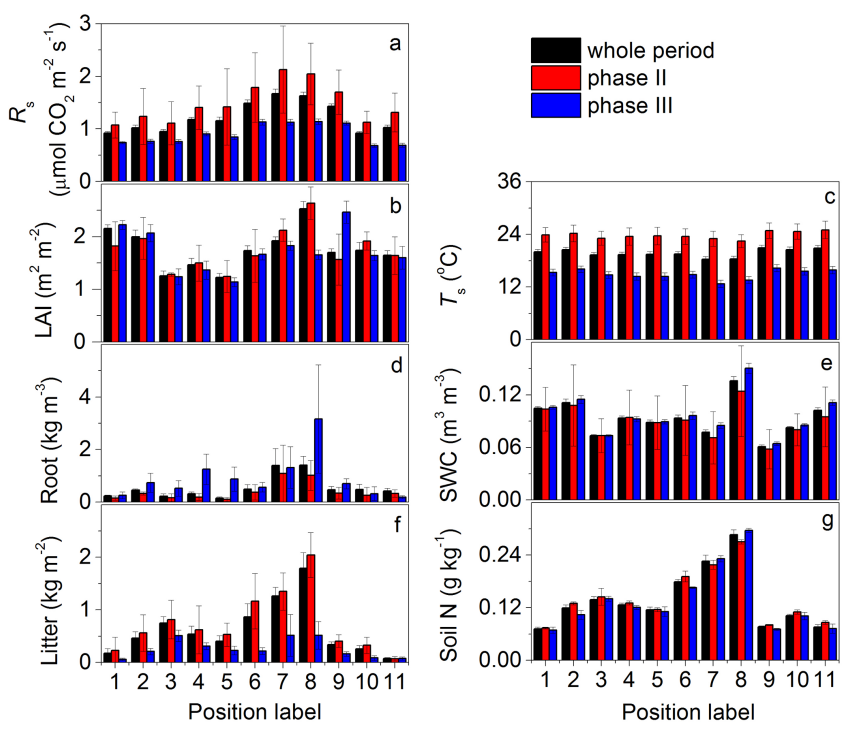

Figure 3. Mean values of soil respiration $\left(R_{\mathrm{S}}\right)$, microhydrometeorological ( $T_{\mathrm{S}}$ and SWC) and plant-related factors (litter, root, soil $\mathrm{N}$ and LAI) at 11 positions over the measurement period (whole period), flower-bearing phase (phase II), and leaf colorationdefoliation phase (phase III) from June to October 2012. Timescales of each phenophases are shown in Fig. 2. $R_{\mathrm{S}}$ : soil respiration $\left(\mu \mathrm{mol} \mathrm{CO} \mathrm{CO}^{-2} \mathrm{~s}^{-1}\right) ; T_{\mathrm{s}}$ : soil temperature $\left({ }^{\circ} \mathrm{C}\right)$; SWC: volumetric soil water content $\left(\mathrm{m}^{3} \mathrm{~m}^{-3}\right)$; Litter: litterfall $\left(\mathrm{kg} \mathrm{m}^{-2}\right)$; Root: root biomass $\left(\mathrm{kg} \mathrm{m}^{-3}\right)$; LAI: leaf area index $\left(\mathrm{m}^{2} \mathrm{~m}^{-2}\right)$; Soil $\mathrm{N}$ : soil nitrogen content at $0-25 \mathrm{~cm}$ soil depths $\left(\mathrm{g} \mathrm{kg}^{-1}\right)$. Error bars represent standard error.

\subsection{Relationships between soil respiration, microhydrometeorological and plant-related factors over the measurement period}

Topographic heterogeneity in $R_{\mathrm{S}}$ was correlated positively with the plant-related factors, like root biomass (Table 3 , Fig. 4a), litterfall (Table 3, Fig. 4b) and soil nitrogen over the measurement period (Table 3, Fig. 4c), but not with the microhydrometeorological factors (i.e., $T_{\mathrm{S}}$ and SWC, $p>0.05$, Table 3 ). Aside from $R_{\mathrm{S}}$, both root biomass and soil nitrogen were correlated positively with litterfall (Fig. 5a, b).

\subsection{Relationship between microhydrometeorological factors, plant-related factors and soil respiration for different phenophases}

During phase II (Fig. 2), the spatial variation in $R_{\mathrm{S}}$ correlated with the spatial variation in root biomass, litterfall and soil nitrogen (Table 3, Figs. 4d, e, f, 6d, f, g). Variation in root biomass, litterfall and soil nitrogen explained the majority ( $>61 \%$ ) of the variation in $R_{\mathrm{S}}$ among the 11 microsites (Table 3, Fig. 4). Regression slopes between $R_{\mathrm{S}}$ and root biomass, litterfall and soil nitrogen were 0.94, 0.51 and 0.77 , respectively (Table 3 ). Based on CART analysis, the root 
Table 1. Average values (standard error in brackets) and CV (\%) for micro-hydrometeorological factors and plant-related factors over the three plant phenophases and measurement period. The time scale for the means was showing in Fig. 2. $R_{\mathrm{S}}:$ soil respiration $(\mu \mathrm{mol}$ $\left.\mathrm{CO}_{2} \mathrm{~m}^{-2} \mathrm{~s}^{-1}\right) ; T_{\mathrm{s}}$ : soil temperature at $10 \mathrm{~cm}$ depth $\left({ }^{\circ} \mathrm{C}\right)$; SWC: volumetric soil water content $\left(\mathrm{m}^{3} \mathrm{~m}^{-3}\right)$; Litter: litterfall $\left(\mathrm{kg} \mathrm{m}{ }^{-2}\right) ; \mathrm{Root}$ root biomass $\left(\mathrm{kg} \mathrm{m}^{-3}\right)$; LAI: leaf area index $\left(\mathrm{m}^{2} \mathrm{~m}^{-2}\right)$; $\mathrm{N}$ : soil nitrogen content at 0-25 $\mathrm{cm}$ depth $\left(\mathrm{g} \mathrm{kg}^{-1}\right)$; Phase I: leaf expansion; Phase II: flower-bearing; Phase III: coloration-defoliation.

\begin{tabular}{lrrrrrr}
\hline \multirow{2}{*}{ Variale } & Phase II & \multicolumn{2}{c}{ Phase III } & \multicolumn{3}{c}{ Measurement period } \\
\cline { 2 - 7 } & mean (SE) & CV\% & mean (SE) & CV\% & mean (SE) & CV\% \\
\hline$R_{\mathrm{S}}$ & $1.49(0.11)$ & 25.2 & $0.900(0.06)$ & 21.3 & $1.21(0.09)$ & 23.5 \\
$T_{\mathrm{S}}$ & $23.8(0.24)$ & 3.40 & $14.9(0.33)$ & 7.40 & $19.7(0.27)$ & 4.60 \\
SWC & $0.0897(0.01)$ & 20.8 & $0.0971(0.01)$ & 24.0 & $0.0931(0.01)$ & 22.0 \\
Litter & $0.737(0.17)$ & 78.5 & $0.262(0.05)$ & 67.7 & $0.629(0.16)$ & 82.0 \\
Root & $0.593(0.15)$ & 84.2 & $0.904(0.25)$ & 92.2 & $0.753(0.14)$ & 64.7 \\
LAI & $1.76(0.12)$ & 22.7 & $1.72(0.12)$ & 23.9 & $1.76(0.12)$ & 21.8 \\
N & $0.181(0.02)$ & 43.5 & $0.135(0.02)$ & 53.3 & $0.138(0.02)$ & 49.1 \\
\hline
\end{tabular}

Table 2. Mean values (standard error in parentheses) of microhydrometeorological and plant-related factors on different slope orientations over the measurement period. $R_{\mathrm{S}}$ : soil respiration $\left(\mu \mathrm{mol} \mathrm{CO}_{2} \mathrm{~m}^{-2} \mathrm{~s}^{-1}\right) ; T_{\mathrm{S}}$ : soil temperature $\left({ }^{\circ} \mathrm{C}\right)$; SWC: volumetric soil water content $\left(\mathrm{m}^{3} \mathrm{~m}^{-3}\right)$; Litter: litterfall $\left(\mathrm{kg} \mathrm{m}^{-2}\right)$; Root: root biomass $\left(\mathrm{kg} \mathrm{m}^{-3}\right)$; LAI: leaf area index $\left(\mathrm{m}^{2} \mathrm{~m}^{-2}\right)$; N: soil nitrogen content at 0-25 $\mathrm{cm}$ soil depths $\left(\mathrm{g} \mathrm{kg}^{-1}\right)$.

\begin{tabular}{lllll}
\hline & Windward & Leeward & North-facing & South-facing \\
\hline$R_{\mathrm{S}}$ & $0.964(0.05)$ & $1.65(0.03)$ & $1.13(0.27)$ & $1.27(0.19)$ \\
$T_{\mathrm{S}}$ & $19.9(0.60)$ & $18.4(0.08)$ & $20.8(0.23)$ & $19.4(0.09)$ \\
SWC & $0.0964(0.02)$ & $0.107(0.04)$ & $0.0819(0.02)$ & $0.0918(0.02)$ \\
Litter & $0.487(0.29)$ & $1.53(0.37)$ & $0.231(0.15)$ & $0.671(0.28)$ \\
Root & $0.309(0.13)$ & $1.405(0.02)$ & $0.460(0.03)$ & $0.322(0.17)$ \\
LAI & $1.80(0.48)$ & $2.22(0.43)$ & $1.70(0.05)$ & $1.47(0.25)$ \\
$\mathrm{N}$ & $0.109(0.03)$ & $0.254(0.04)$ & $0.0848(0.02)$ & $0.141(0.03)$ \\
\hline
\end{tabular}

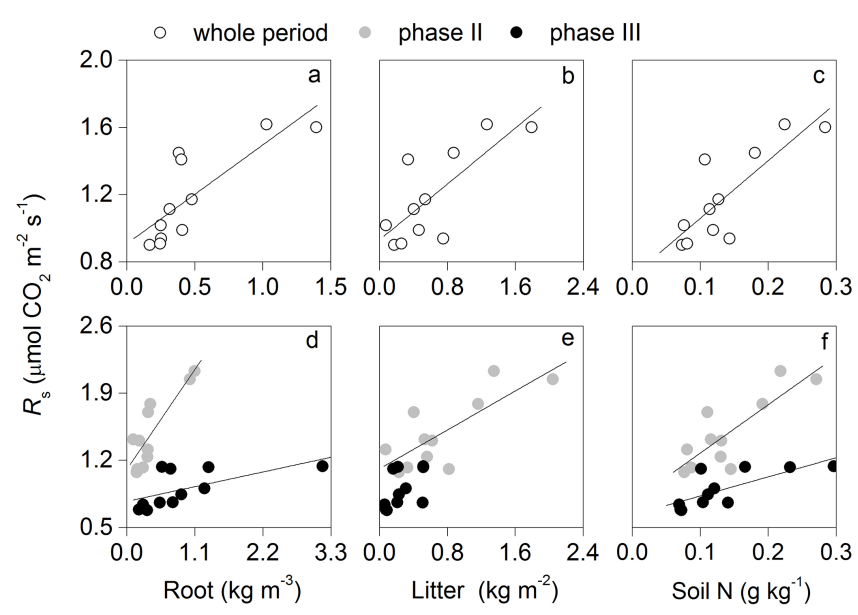

Figure 4. Relationships between soil respiration $\left(R_{\mathrm{S}}\right)$ and root biomass, and litterfall and soil nitrogen over the measurement period (open circles) and during flower-bearing (phase II; gray circles) and leaf coloration-defoliation (phase III; black circles) phase. Lines are linear regressions with $p<0.05$. Equations, $R^{2}$, and $p$ values are given in Table 3.
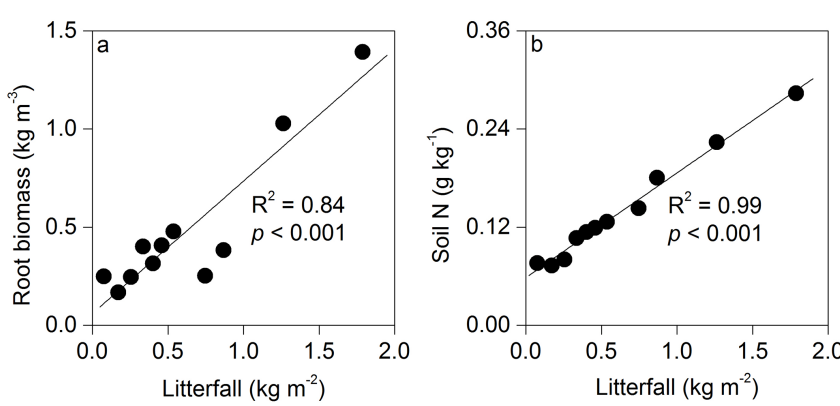

Figure 5. Relationships between litterfall and root (a), and soil nitrogen content (soil N) (b) over the measurement period.

biomass was the most significant factor affecting the spatial variation in $R_{\mathrm{S}}$ during phase II (Fig. 7a).

During phase III (Fig. 2), spatial variation in $R_{\mathrm{S}}$ was strongly correlated to the spatial variation in root biomass and soil nitrogen content (Table 3, Figs. 4d, f, 6k, n). Variation in soil nitrogen content and root biomass explained 56 and $39 \%$ of the variation in $R_{\mathrm{S}}$ among the 11 microsites, respectively (Table 3, Fig. 4d, f). Regression slopes between $R_{\mathrm{S}}$ and root biomass and $R_{\mathrm{S}}$ and soil nitrogen content were 0.14 
Table 3. Regression equations between $R_{\mathrm{S}}(y)$ and different microhydrometeorological and plant-related factors $(x)$ for the measurement period and flower-bearing (phase II) and leaf coloration-defoliation phase (phase III). $T_{\mathrm{S}}$ : soil temperature $\left({ }^{\circ} \mathrm{C}\right)$; SWC: volumetric soil water content $\left(\mathrm{m}^{3} \mathrm{~m}^{-3}\right)$; Litter: litterfall $\left(\mathrm{kg} \mathrm{m}^{-2}\right)$; Root: root biomass $\left(\mathrm{kg} \mathrm{m}^{-3}\right)$; LAI: leaf area index $\left(\mathrm{m}^{2} \mathrm{~m}^{-2}\right)$; $\mathrm{N}$ : soil nitrogen content at $0-25 \mathrm{~cm}$ soil depths $\left(\mathrm{g} \mathrm{kg}^{-1}\right)$.

\begin{tabular}{lllrr}
\hline Phase & Factors & Equation & $R^{2}$ & $p$ \\
\hline Whole period & Root biomass & $y=0.51 x+0.93$ & 0.61 & 0.004 \\
& Litterfall & $y=0.43 x+0.95$ & 0.59 & 0.005 \\
& $T_{\text {S }}$ & $y=-0.18 x+4.84$ & 0.34 & 0.061 \\
& SWC & $y=0.89 x+1.13$ & $<0.01$ & 0.852 \\
& LAI & $y=0.28 x+0.73$ & 0.14 & 0.256 \\
& N & $y=3.48 x+0.74$ & 0.68 & 0.002 \\
\hline Phase II & Root biomass & $y=0.64 x+1.11$ & 0.72 & 0.001 \\
& Litterfall & $y=0.51 x+1.11$ & 0.61 & 0.004 \\
& $T_{\text {S }}$ & $y=-0.23 x+7.00$ & 0.25 & 0.118 \\
& SWC & $y=-0.27 x+1.51$ & $<0.01$ & 0.969 \\
& LAI & $y=0.48 x+0.64$ & 0.26 & 0.108 \\
& N & $y=5.04 x+0.77$ & 0.68 & 0.001 \\
\hline \multirow{2}{*}{ Phase III } & Root biomass & $y=0.14 x+0.77$ & 0.37 & 0.048 \\
& Litterfall & $y=0.55 x+0.76$ & 0.26 & 0.112 \\
& $T_{\text {S }}$ & $y=-0.09 x+2.24$ & 0.26 & 0.105 \\
& SWC & $y=0.39 x+0.86$ & $<0.01$ & 0.887 \\
& LAI & $y=0.11 x+0.71$ & 0.05 & 0.492 \\
& N & $y=1.99 x+0.63$ & 0.56 & 0.008 \\
\hline
\end{tabular}

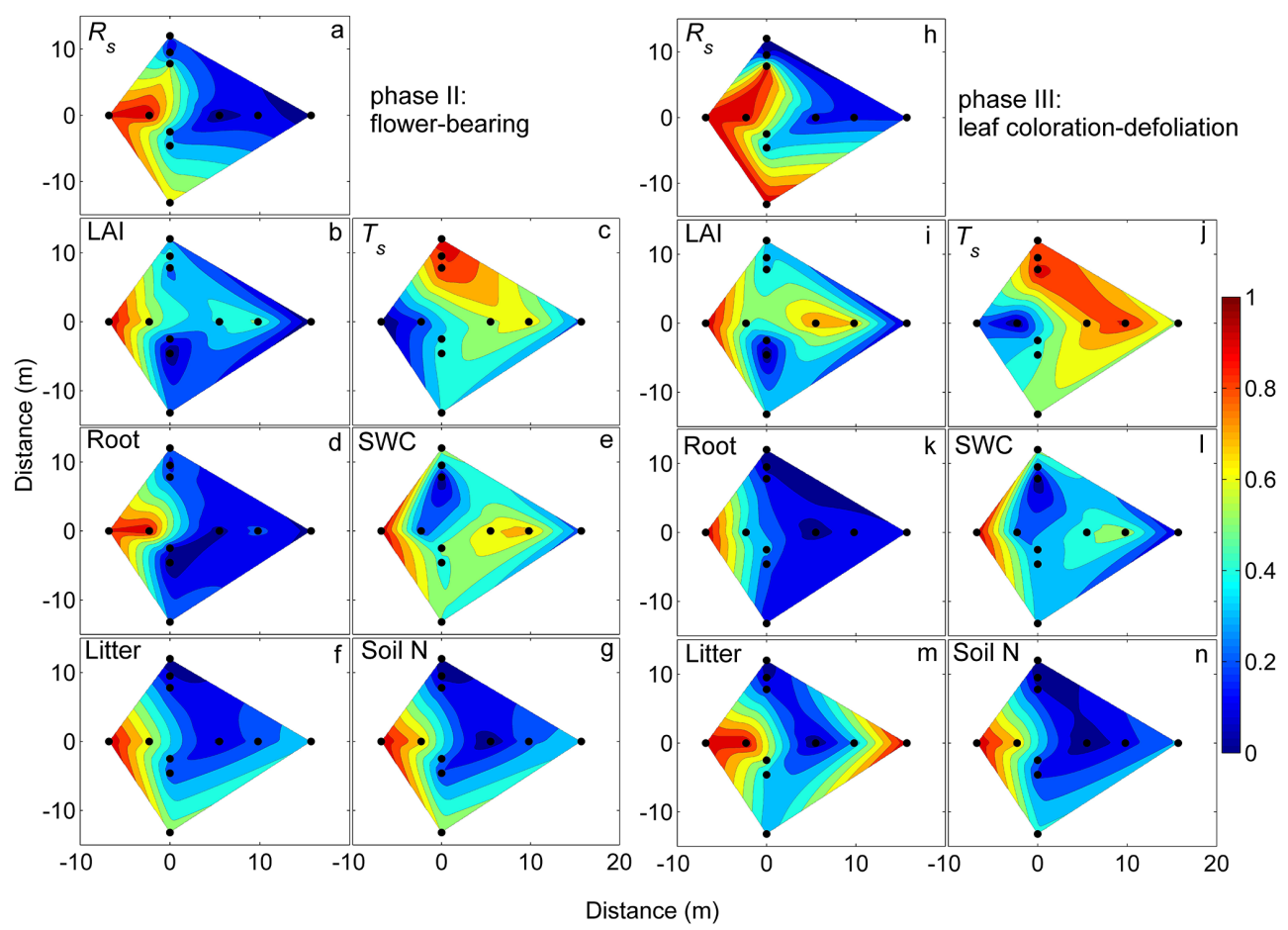

Figure 6. Spatial patterns of soil respiration $\left(R_{\mathrm{S}}\right)$, microhydrometeorological $\left(T_{\mathrm{S}}\right.$ and SWC) and plant-related factors (Litter, Root, Soil N and LAI) over the sand dune in flower-bearing phase (phase II) and coloration-defoliation phase (phase III). Data values for all variables were normalized into the range of $0-1$ using feature scaling method $\left(X_{\text {normalized }}=\left(X-X_{\min }\right) /\left(X_{\max }-X_{\min }\right)\right)$. Black dots represent the measurement positions as shown in Fig. 1. 
a: Phase II

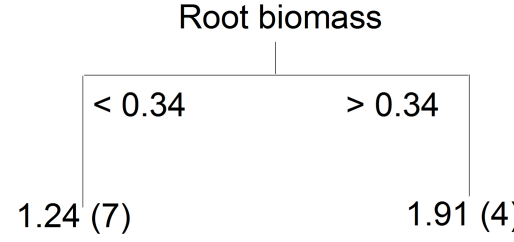

b. Phase III

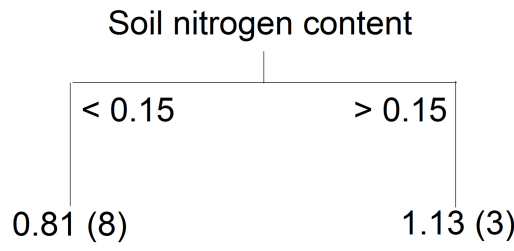

Figure 7. Results of CART analysis with key factors explaining spatial variability in soil respiration at the flower-bearing (a) and coloration-defoliation phases (b). Predictor variables are depicted at the top of each branch. Their critical values are shown at the side of each branch and the mean soil $\mathrm{CO}_{2}$ efflux (including number of observations in parentheses) is reported below the terminal nodes.

and 0.63 (Table 3). Based on CART analysis, soil nitrogen content affected the spatial variation in $R_{\mathrm{S}}$ the most during phase III (Fig. 7b).

\section{Discussion}

\subsection{Spatial patterns in soil respiration with respect to plant patchiness}

The observed pattern that $R_{\mathrm{S}}$ on the leeward slope was highest among the four slope orientations, was consistent with the findings of Chai et al. (2012), who found that $R_{\mathrm{S}}$ on leeward slopes was over two times greater than $R_{\mathrm{S}}$ on windward slopes of a sand dune. The greater $R_{\mathrm{S}}$ on leeward slopes may be explained by the presence of larger patches of vegetation, most likely supported by the better soil conditions induced by the "fertility island" effect, addressed earlier (Table 2). Associated with the "fertility island" effect is the enrichment of the soil near the plants by the annual casting of photosynthates and nitrogen compounds with annual litterfall. In contrast, on the windward slope the level of soil enrichment is limited as a result of smaller vegetation patches, leading to suppression of $R_{\mathrm{S}}$. Higher supply of photosynthetic products and soil nitrogen in the vicinity of the plants was reported in previous studies by Scott-Denton et al. (2003) and Tang et al. (2005).

However, we did not find consistent patterns in $R_{\mathrm{S}}$ between height positions. As a comparison, Chai et al. (2012) observed earlier that $R_{\mathrm{S}}$ was lower in the lower positions, whereas Xu and Wan (2008) and Liu et al. (2010) found the opposite result. The magnitude of $R_{\mathrm{S}}$ at a given slope position was consistent with those of plant-related factors (Table 3, Fig. 4$), R_{\mathrm{S}}$ being highest at positions closest to the plants re- gardless of height gradients along the slopes. It is therefore concluded that topographic position or height within the sand dune per se is a poor predictor of $R_{\mathrm{s}}$.

\subsection{Plant drivers of the topographic variation in soil respiration over the measurement period}

Our present finding that plant-related factors drive the topographic variation in $R_{\mathrm{S}}$ over a sand dune (Table 3, Fig. 4) was consistent with those of Sponseller and Fisher (2008). They reported that spatial patterns in $R_{\mathrm{S}}$ in the Sonoran Desert were related to plant size and productivity, but unrelated to soil water. Desert ecosystems are generally limited with substrate supply due to their low living biomass and accumulated soil organic matter, but feature large spatial heterogeneity in respiration substrate due to the "fertility-island" effect (Gold et al., 1995; Xie et al., 2001). This can be supported by large CVs (49.1, 64.7 and $82.0 \%$ ) in plant-related factors of our study. In contrast, CVs for the hydrometeorological factors were much smaller (4.6 and $22.0 \%$ ). Positive relationships between plant-related factors (litterfall, soil nitrogen and root biomass), together with their positive effects on $R_{\mathrm{S}}$ (Figs. 4 , 6 ), emphasized that spatial variation in supply of respiration substrate regulated spatial variation in $R_{\mathrm{s}}$. Current photosynthate is supplied for root and rhizosphere respiration (Högberg et al., 2001; Tang et al., 2005; Han et al., 2014). Litterfall is supplied for heterotrophic microbe respiration (Reichstein et al., 2002; Zhou et al., 2013). These processes are influenced by soil nitrogen content (Allison et al., 2008; Deng et al., 2010). These findings support our first hypothesis that topographic heterogeneity in $R_{\mathrm{S}}$ was controlled by the respiration substrate supply provided by plants. In contrast, many studies in forests and grasslands report that topographic heterogeneity in $R_{\mathrm{S}}$ can be suitably explained by spatial heterogeneity in $T_{\mathrm{S}}$ and SWC (Kang et al., 2003; Liu et al., 2010). We suggest that future studies on spatially scaling up soil respiration in desert ecosystems should consider the spatial variation in substrate supply more than temperature.

Our finding that plants controlled the topographic variation in $R_{\mathrm{S}}$ over a fixed sand dune, along with similar findings by other studies (Moyano et al., 2008; Kuzyakov and Gavrichkova, 2010; Han et al., 2014), challenge the legitimacy of empirical models of $R_{\mathrm{S}}$ at the sand-dune scale. As an alternative, we suggest that photosynthesis-related parameters (or variables, e.g., root biomass and litterfall) ought to be incorporated into these models for an improved characterization of soil-plant relationships in desert ecosystems.

\subsection{Drivers of topographic heterogeneity in soil respiration as a function of plant phenology}

In our study, topographic heterogeneity in $R_{\mathrm{S}}$ at the flowerbearing phase (phase II) was significantly related to root biomass, litterfall and soil nitrogen content. But with consideration of interactions between these plant-related factors, 
only root biomass was identified as the most important driving factor. In contrast, topographic heterogeneity in $R_{\mathrm{S}}$ at the leaf coloration and defoliation phase (phase III) was significantly related to root biomass and soil nitrogen content, but only soil nitrogen content was identified as important. Our results support our second hypothesis that drivers of topographic variation in $R_{\mathrm{S}}$ varies with plant phenophases.

From phase II to III, photosynthetic pigments and leaf photosynthesis declined, and induced large decreases in current photosynthate supply for roots and rhizosphere microorganisms (Hanson et al., 2000; Fu et al., 2002; Sey et al., 2010). Decomposition of litterfall results in a high percentage of recalcitrant substrates during phase II, but addition of fresh litterfall during phase III increases the percentage of liable substrates (Lebret et al., 2001; Regina, 2001; Ochieng and Erftemeijer, 2002). Thus, changes in substrate supply between the two phenophases could result in seasonal changes in the relative contribution of autotrophic and heterotrophic respiration to total $R_{\mathrm{S}}$. Root respiration contributes largely to total $R_{\mathrm{S}}$ during the growing season, but heterotrophic respiration contributes largely during the senescence season (Fu et al., 2002; Sey et al., 2010; Mauritz and Lipson, 2013). Specifically, in our study, autotrophic respiration may contribute largely to the total $R_{\mathrm{S}}$ during the phase II, but heterotrophic respiration may contribute largely during the phase III. We could not test this inference directly due to lack of independent measurements of different $R_{\mathrm{S}}$ components. However, some of our results can indirectly confirm this inference.

In our study, $R_{\mathrm{S}}$ was sensitive to root biomass during phase II, but less sensitive during phase III, indicating a decrease in relative contribution of root respiration to $R_{\mathrm{S}}$ during phase III. $R_{\mathrm{S}}$ was related to litterfall during phase II, unlike during phase III, indicating the switched substrate pool and disproportionate addition of fresh litterfall. However, the controlling factors of autotrophic and heterotrophic respiration can be quite different. Autotrophic respiration is shown in other studies to be largely controlled by root biomass and soil nitrogen (Tu et al., 2013; Zhou et al., 2014), and heterotrophic respiration by the amount of litterfall and soil nitrogen (Yan et al., 2010; Sayer et al., 2011). Thus, the key factor controlling the variation in $R_{\mathrm{S}}$ can be different for the different plant phenophases.

There has been a clear lack of understanding on the effects of plant phenology on the driving forces of topographic heterogeneity in $R_{\mathrm{S}}$ (Janssens et al., 2004; Bahn et al., 2008). In this sense, our work provides new knowledge of driving mechanisms of topographic heterogeneity in $R_{\mathrm{S}}$ as affected by plant phenology. Based on our work, we suggest that the influences of plant phenology on both current photosynthate and litterfall supply should not be neglected, and partitioning $R_{\mathrm{S}}$ is necessary for future studies on the spatial heterogeneity in $R_{\mathrm{S}}$.

\section{Conclusions}

Soil respiration was highest on the leeward slope, and the lowest on the windward slope. Topographic heterogeneity in $R_{\mathrm{S}}$ was related to the variation in supply of both recent photosynthetic products and litterfall, indicating that plants largely control the topographic heterogeneity in $R_{\mathrm{S}}$ over a sand dune. Due to the "fertility island" effect, spatial patterns of $R_{\mathrm{S}}$ on different slopes were related to the distance from plant patches, regardless of microtopographic relief. Drivers of topographic heterogeneity in $R_{\mathrm{S}}$ varied with plant phenophases. Our findings highlight the importance of plants in controlling the spatial variation in $R_{\mathrm{S}}$ in desert ecosystems. We suggest that future studies on the spatial variation in $R_{\mathrm{S}}$ should consider both the spatial and the temporal effects of vegetation, especially in desert environments.

Acknowledgements. We acknowledge the support obtained from the National Natural Science Foundation of China (NSFC) (31270755 and 31361130340, 31200537), the Academy of Finland (proj. no. 14921), Beijing Forestry University and the University of Eastern Finland. This work is related to the ongoing Finnish-Chinese research collaboration project EXTREME, between Beijing Forestry University and the University of Eastern Finland. Thanks to Graham Forbes for valuable comments and language revisions and to Huishu Shi, Yuming Zhang, Wei Feng, Sijing Li, Zhihao Chen, Siling Tang, Yajuan Wu and Yuan Li for their assistance with the field measurements and instrumentation maintenance.

Edited by: J.-A. Subke

\section{References}

Allison, S. D., Czimczik, C. I., and Treseder, K. K.: Microbial activity and soil respiration under nitrogen addition in Alaskan boreal forest, Glob. Change Biol., 14, 1-13, 2008.

Asaeda, T. and Rashid, M. H.: Nutrient retention associated with phenological features in Sparganium erectum stands in a lowland stream, River Res. Appl., 31, 207-215, 2015..

Austin, A. T.: Has water limited our imagination for aridland biogeochemistry?, Trends Ecol. Evol., 26, 229-235, 2011.

Bahn, M., Rodeghiero, M., Anderson-Dunn, M., Dore, S., Gimeno, C., Drösler, M., Williams, M., Ammann, C., Berninger, F., Flechard, C., Jones, S., Balzarolo, M., Kumar, S., Newesely, C., Priwitzer, T., Raschi, A., Siegwolf, R., Susiluoto, S., Tenhunen, J., Wohlfahrt, G., and Gernusca, A.: Soil respiration in European grasslands in relation to climate and assimilate supply, Ecosystems, 11, 1353-1367, 2008.

Bond-Lamberty, B. and Thomson, A.: Temperature-associated increases in the global soil respiration record, Nature, 464, 579582, 2010a.

Bond-Lamberty, B. and Thomson, A.: A global database of soil respiration data, Biogeosciences, 7, 1915-1926, doi:10.5194/bg-71915-2010, 2010b. 
Breimann L. Friedman, J. Stone, C. J., and Olshen, R. A.: Classification and regression trees, Chapman \& Hall/CRC, Wadsworth, Belmont, California, 1984.

Chai, H., Feng, J., and Jing, Y.: Spatial distribution and change trait of soil respiration at the dunes in Hoqin Sand Land, Arid Land Geogr., 3, 463-472, 2012.

Davidson, E. A. and Janssens, I. A.: Temperature sensitivity of soil carbon decomposition and feedbacks to climate change, Nature, 440, 165-173, 2006.

Davidson, E. A., Belk, E., and Boone, R. D.: Soil water content and temperature as independent or confounded factors controlling soil respiration in a temperate mixed hardwood forest, Glob. Change Biol., 4, 217-227, 1998.

DeForest, J. L., Noormets, A., McNulty, S. G., Sun, G., Tenney, G., and Chen, J.: Phenophases alter the soil respiration-temperature relationship in an oak-dominated forest, Int. J. Biometeorol., 51, 135-144, 2006.

Deng, Q., Zhou, G., Liu, J., Liu, S., Duan, H., and Zhang, D.: Respiration of soil respiration to elevated carbon dioxide and nitrogen addition in subtropical forest ecosystems in China, Biogeosciences, 7, 315-328, doi:10.5194/bg-7-315-2010, 2010.

Dungan, R. J., Whitehead, D., and Duncan, R. P.: Seasonal and temperature dependence of photosynthesis and respiration for two co-occurring broad-leaved tree species with contrasting leaf phenology, Tree Physiol., 23, 561-568, 2003.

Feng, W., Zhang, Y., Wu, B., Zha, T., Jia, X., Qin, S., Shao, C., Liu, J., Lai, Z., and Fa, K.: Influence of disturbance on soil respiration in biologically crusted soil during the dry season, The Scientific World J., 2013, 408560, doi:10.1155/2013/408560, 2013.

Fu, S., Cheng, W., and Susfalk, R.: Rhizosphere respiration varies with plant species and phenology: a greenhouse pot experiment, Plant Soil, 239, 133-140, 2002.

Geng, Y., Wang, Y., Yang, K., Wang, S., Zeng, H., Baumann, F., Kuehn, P., Scholten, T., and He, J.: Soil respiration in Tibetan Alpine Grasslands: Belowground biomass and soil moisture, but not soil temperature, best explain the large-scale patterns, PLoS ONE, 7, e34968. doi:10.1371/journal.pone.0034968, 2012.

Gold, W. G. and Bliss, L. C.: Water limitations and plant community development in a polar desert, Ecology, 76, 1558-1568, 1995.

Han, G., Luo, Y., Li, D., Xia, J., Xing, Q., and Yu, J.: Ecosystem photosynthesis regulates soil respiration on a diurnal scale with a short-term time lag in a coastal wetland, Soil Biol. Biochem., 68, 85-94, 2014.

Hanson, P. J., Edwards, N. T., Garten, C. T., and Andrews, J. A.: Separating root and soil microbial contributions to soil respiration: a review of methods and observations, Biogeochemistry, 48, 115-146, 2000.

Hook, P. B., Burke, I. C., and Lauenroth, W. K.: Heterogeneity of soil and plant $\mathrm{N}$ and $\mathrm{C}$ associated with individual plants and openings in North American short grass steppe, Plant Soil, 138, 247-256, 1991.

Högberg, P., Nordgren, A., Buchmann, N., Taylor, A. F. S., Ekblad, A., Högberg, M. N., Nyberg, G., Ottosson-Löfvenius, M., and Read, D. J.: Large-scale forest girdling shows that current photosynthesis drives soil respiration, Nature, 411, 789-792, 2001.

Janssens, I. A., Carrara, A., and Ceulemans, R.: Annual $Q_{10}$ of soil respiration reflects plant phenological patterns as well as temperature sensitivity, Glob. Change Biol., 10, 161-169, 2004.
Jia, X., Zhan, T., Wu, B., Zhang, Y., Chen, W., Wang, X., Yu, H., and He, G.: Temperature response of soil respiration in a Chinese pine plantation: hysteresis and seasonal vs. diel $\mathrm{Q}_{10}$, PLoS ONE, 8, e57858. doi:10.1371/journal.pone.0057858, 2013.

Kang, S., Doh, S., Lee, D. S., Lee, D., Jin, V. L., and Kimball, J. S.: Topographic and climatic controls on soil respiration in six temperate mixed-hardwood forest slopes, Korea, Glob. Change Biol., 9, 1427-1437, 2003.

Kuzyakov, Y. and Gavrichkova, O.: Time lag between photosynthesis and carbon dioxide efflux from soil: a review of mechanisms and controls, Glob. Change Biol., 16, 3386-3406, 2010.

Lebret, M., Nys, C., and Forgeard, F.: Litter production in an Atlantic beech (Fagus sylvatica L.) time sequence, Ann. For. Sci., 58, 755-768, 2001.

Lloyd, J. and Taylor, J. A.: On the temperature dependence of soil respiration, Funct. Ecol., 8, 315-323, 1994.

Li, J., Zhao, C., Zhu, H., Li, Y., and Wang, F.: Effect of plant species on shrub fertile island at an oasis-desert ecotone in the South Junggar Basin, China, J. Arid Environ., 71, 350-361, 2007.

Li, P. X., Wang, N., He, W. M., Krüsi, B. O., Gao, S. Q., Zhang, S. M., Yu, F. H., and Dong, M.: Fertile islands under Artemisia ordosica in inland dunes of northern China: effects of habitats and plant developmental stages, J. Arid Environ., 72, 953-963, 2008.

Liu, W., Xu, W., Hong, J., and Wan, S.: Interannual variability of soil microbial biomass and respiration in responses to topography, annual burning and $\mathrm{N}$ addition a semiarid temperature steppe, Geoderma, 158, 259-267, 2010.

Luo, J., Chen, Y., Wu, Y., Shi, P., She, J., and Zhou, P.: Temporal-spatial variation and controls of soil respiration in different primary succession stage on glacier forehead in Gongga Mountain, China, PLoS ONE, 7, e42354, doi:10.1371/journal.pone.0042354, 2012.

Luo, Y. Q.: Terrestrial carbon-cycle feedback to climate warming, Annu. Rev. Ecol. Evol. S., 38, 683-712, 2007.

Mahall, B. E. and Callaway, R. M.: Root communication mechanisms and intracommunity distributions of two Mojave Desert shrubs, Ecology, 73, 2145-2151, 1992.

Martin, J. G. and Bolstad, P. V.: Variation of soil respiration at three spatial scales: Components within measurements, intra-site variation and patterns on the landscape, Soil Biol. Biochem., 41, 530-543, 2009.

Mauritz, M. and Lipson, D. L.: Altered phenology and temperature sensitivity of invasive annual grasses and forbs changes autotrophic and heterotrophic respiration rates in a semi-arid shrub community, Biogeosciences Discuss., 10, 6335-6375, doi:10.5194/bgd-10-6335-2013, 2013.

Moyano, F. E., Kutsch, W. L., and Rebmann, C.: Soil respiration fluxes in relation to photosynthetic activity in broad-leaf and needle-leaf forest stands, Agr. Forest Meteorol., 148, 135-143, 2008.

Ngao, J., Epron, D., Delpierre, N., Bréda, N., Granier, A., and Longdoz, B.: Spatial variability of soil $\mathrm{CO}_{2}$ efflux linked to soil parameters and ecosystem characteristics in a temperate beech forest, Agr. Forest Meteorol., 154, 136-146, 2012.

Ochieng, C. A. and Erftemeijer, P. L.: Phenology, litterfall and nutrient resorption in Avicennia marina (Forssk.) Vierh in Gazi Bay, Kenya, Trees, 16, 167-171, 2002. 
Osono, T.: Diversity, resource utilization, and phenology of fruiting bodies of litter-decomposing macrofungi in subtropical, temperate, and subalpine forest, J. Forest Res.-Jpn., 20, 60-68, 2014.

Parker, K. C.: Topography, substrate, and vegetation patterns in the northern Sonoran Desert, J. Biogeogr., 18, 151-163, 1991.

Poulter, B., Frank, D., Ciais, P., Myneni, R. B., Andela, N., Bi, J., Broquet, G., Canadell, J. G., Chevallier, F., Liu, Y. Y., Running, S. W., Sitch, S., and Van der Werf, G. R.: Contribution of semiarid ecosystems to interannual variability of the global carbon cycle, Nature, 509, 600-603, 2014.

Raich, J. W. and Schlesinger, W. H.: The global carbon dioxide flux in soil respiration and its relationship to vegetation and climate, Tellus B, 44, 81-99, 1992.

Raich, J. W., Potter, C. S., and Bhagawati, D.: Interannual variability in global soil respiration, 1980-94, Glob. Change Biol., 8, 800-812, 2002.

Regina, I. S.: Litter fall, decomposition and nutrient release in three semi-arid forests of Duero basin, Spain, Foresty, 74, 347-358, 2001.

Reichstein, M., Tenhunen, J. D., Roupsard, O., Ourcival, J.-M., Rambal, S., Miglietta, F., Peressotti, A., Pecchiari, M., Tirone, G., and Valentini, R.: Severe drought effects on ecosystem $\mathrm{CO}_{2}$ and $\mathrm{H}_{2} \mathrm{O}$ fluxes at three Mediterranean evergreen sites: revision of current hypotheses?, Glob. Change Biol., 8, 999-1017, 2002.

Richerson, P. J. and Lum, K.: Patterns of plant species diversity in California: relation to weather and topography, Am. Nat., 116, 504-536, 1980.

Roles, B., Donders, S., Werger, M. J., and Dong, M.: Relation of wind-induced sand displacement to plant biomass and plant sand-binding capacity, Acta Bot. Sin., 43, 979-982, 2001.

Safriel, U. and Adeel, Z.: Dryland ecosystems, II, in: Ecosystems and human well-being: current state and trends, Vol 1, edited by: Hassan, R., Scholes, R., and Neville, A., Island Press, Washingon, DC, 623-662, 2005.

Sayer, E. J., Heard, M. S., Grant, H. K., Marthews, T. R., and Tanner, E. V. J.: Soil carbon release enhanced by increased tropical forest litterfall, Nature Climate Change, 1, 304-307, 2011.

Schlesinger, W. H. and Andrews, J. A.: Soil respiration and the global carbon cycle, Biogeochemistry, 48, 7-20, 2000.

Schlesinger, W. H. and Raikes, J. A.: On the spatial pattern of soil nutrients in desert ecosystems, Ecology, 77, 364-374, 1996.

Scott-Denton, L. E., Sparks, K. L., and Monson, R. K.: Spatial and temporal controls of soil respiration rate in a high-elevation, subalpine forest, Soil Biol. Biochem., 35, 525-534, 2003.

Sey, B. K., Manceur, A. M., Whalen, J. K., Gregorich, E. G., and Rochette, P.: Root-derived respiration and nitrous oxide production as affected by crop phenology and nitrogen fertilization, Plant Soil, 326, 369-379, 2010.

Sponseller, R. A. and Fisher, S. G.: The influence of drainage networks on patterns of soil respiration in a desert catchment, Ecology, 89, 1089-1100, 2008.
Stock, W. D., Dlamini, T. S., and Cowling, R. M.: Plant induced fertile islands as possible indicators of desertification in a succulent desert ecosystem in northern Namaqualand, South Africa, Plant Ecol., 142, 161-176, 1999.

Tamai, K.: Effects of environmental factors and soil properties on topographic variations of soil respiration, Biogeosciences, 7 , 1133-1142, doi:10.5194/bg-7-1133-2010, 2010.

Tang, J., Baldocchi, D. D., and Xu, L.: Tree photosynthesis modulates soil respiration on a diurnal time scale, Glob. Change Biol. 11, 1298-1304, 2005.

Thompson, D. B., Walker, L. R., Landau, F. H., and Stark, L. R.: The influence of elevation, shrub species, and biological soil crust on fertile islands in the Mojave Desert, USA, J. Arid Environ., 61, 609-629, 2005.

Tu, L., Hu, X., Zhang, J., Li, X., Hu, H., Liu, L., and Xiao, Y.: Nitrogen addition simulates different components of soil respiration in a subtropical bamboo ecosystem, Soil Biol. Biochem., 58, 255-264, 2013.

Venables, W. N. and Ripley, B. D.: Modern applied statistics with S-Plus. Springer Press, NewYork, 2002.

Wang, B., Zha, T. S., Jia, X., Wu, B., Zhang, Y. Q., and Qin, S. G: Soil moisture modifies the response of soil respiration to temperature in a desert shrub ecosystem, Biogeosciences, 11, 259-268, doi:10.5194/bg-11-259-2014, 2014.

Xie, G. and Steinberger, Y.: Temporal patterns of $\mathrm{C}$ and $\mathrm{N}$ under shrub canopy in a loessial soil desert ecosystem, Soil Biol. Biochem., 33, 1371-1379, 2001.

$\mathrm{Xu}, \mathrm{W}$. and Wan, S.: Water- and plant-mediated responses of soil respiration to topography, fire, and nitrogen fertilization in a semiarid grassland in north China, Soil Biol. Biochem., 40, 679687, 2008.

Yan, L., Chen, S., Huang, J., and Lin, G.: Different responses of auto- and heterotrophic soil respiration to water and nitrogen addition in a semiarid temperate steppe, Glob. Change Biol., 16, 2345-2357, 2010.

Yuste, J. C., Janssens I. A., Carrara, A., and Ceulemans, R.: Annual $Q_{10}$ of soil respiration reflects plant phenological patterns as well as temperature sensitivity, Glob. Change Biol., 10, 161169, 2004.

Zhou, L., Zhou, X., Zhang, B., Lu, M., Luo, Y., Liu, L., and Li, B.: Different responses of soil respiration and its components to nitrogen addition among biomes: a meta-analysis, Glob. Change Biol., 7, 2332-2343, 2014.

Zhou, Z., Zhang, Z., Zha, T., Luo, Z., Zheng, J., and Sun, J.: Predicting soil respiration using carbon stock in roots, litter and soil organic matter in forest of Loss Plateau in China, Soil Biol. Biochem., 57, 135-143, 2013. 